\title{
Journeys From the Horizons of History: Text, Trial and Tales in the Construction of Narratives of Pain
}

\section{Premesh Lalu and Brent Harris}

Horizon: limit of mental perception, understanding, experience and interest. (Concise Oxford Dictionary)

If the subaltern can speak then, thank god, the subaltern is not a subaltern any more. (Spivak 1989:283)

Judicial commission? Church service? Theatre? Group therapy? Funeral? In the end, as in the beginning it was none of those things. (Beresford 1996)

In its quest to uncover the truth about gross human rights violations, the Truth and Reconciliation Commission (TRC) has brought the discussion on facts, truth, memory, evidence and the production of history into the public domain in an unprecedented manner. South Africa's repressed voices, its traumas, have become a feature of intense public debate. History, it seems, is being made, written, spoken and used to build a new nation. In the perception of the TRC, history lies waiting to be uncovered - the facts are self-explanatory, and when compiled will provide a common past for all South Africans - or so it is assumed. Premised on the desire to reconcile and unite the nation, the TRC has embarked upon a project of making memories "widely available so that the memory of a country can be restored and our whole past can be acknowledged by all" (Krog 1995:118).

The descriptions of the experience of tyranny and trauma - the stories that abound from victims and survivors, bystanders and perpetrators - shift the boundaries of the commission and destabilise linear constructions of a "shared national memory". But what occurs when these stories are subjected to the ritual procedures of contextualisation by the TRC and when they are appropriated by academics who will be expected to provide a synthesis out of what appears to be disparate episodes of personal trauma? The question that needs to be asked, 
in the end, as in the beginning, to echo Dipesh Chakrabarty in another postcolonial setting, is who speaks for South African pasts?

In Question and Answer: Forms of Dialogic Understanding (1982), Hans Robert Jauss reproaches historians for failing to explore the concept of "horizon" when interpreting texts. The horizon, he suggests, is central to interpretations of texts, and "constitutes all structures of meaning related to human action and primary modes of comprehending the world" (Jauss 1982:197). For Jauss, the failure to acknowledge this concept has resulted in a mediative distance between the alien horizons of the text and the interpretive horizons of the historian (199207).

The title for this article, and indeed much of what we will argue, draws inspiration from Jauss's theorisation of the concepts of horizon, reception, and construction. The problem we confront relates to the way we receive, interpret, and apply texts without cognisance of the ways our horizons advance, limit, and intersect with a multiplicity of meanings that might not have been foreseen by the text's contemporaries. What are the distances between public encounters with the past on the one hand, and on the other the testimonies heard by the commission or readings of trauma offered by social scientists and historians? In this paper we wish to offer a tentative response to this question by reflecting on various readings of the trial of Andrew Zondo and the public testimony of Lephina Zondo at the TRC. We are interested in the ways in which truths, and histories, are produced "by virtue of multiple forms of constraint" (Foucault 1980:131).

\section{The Burden of Positivism and Context}

In a recent consideration of the approaches to evidence, Carlo Ginzburg argues that, apart from certain classic traditions, the epistemological parting of ways between the historian and the judge are quite apparent. Ginzburg's unravelling of the complex procedures entailed in the historians' encounter with evidence, he claims, is far from being a retreat into positivism. Evidence, in his view, is not "an open window that gives us direct access to reality", but neither is it "a wall, which by definition precludes any access to reality" (Ginzburg 1994:294). Both Carlo Ginzburg and Arnold I. Davidson argue that the tension between the historian and the judge is located in their divergent objectives. They see the difference in that, for the judge, evidence is used "in the service of establishing a just verdict" based on absolute certainty of guilt, "beyond any reasonable doubt" (Davidson 1994:307-309), while for the historian, a plausible interpretation of the evidence "is relevant for securing a truthful account of events" (Ginzburg 1994:302). 
In 1987, Skotaville Publishers issued Fatima Meer's book, The Trial of Andrew Zondo: A Sociological Insight. Meer, who was a lecturer in the Sociology Department at the University of Natal,Durban at the time, set out to record the events and circumstances surrounding Andrew Zondo's trial and his subsequent execution.

In her book Fatima Meer seems to have inadvertently opened up the question of the differences between approaches to evidence within the legal system, and the approaches adopted by historians and sociologists. Her book is an attack on the positivism and the reductive, almost anti- historical, tendencies of the South African legal system in determining Andrew Zondo's guilt. In its place she substituted a reading of Zondo's life that sought to contextualise Zondo beyond 23 December 1985, the day on which he planted a bomb at an Amanzimtoti shopping centre on the Natal south coast. Zondo was sentenced to death five times for planting this bomb. As Meer tells us in the opening lines of her book, the bomb resulted in the death of "[a] baby, a young boy, a girl and two women", and the injury of "seventeen white men and boys, twenty- eight white women and girls, one Black man and two Black women" (Meer 1987:3).

Far from being a narrative account of the trial proceedings, Meer's book seems to have been an intervention in and a challenge to the procedures of legal institutions in South Africa, especially their positivist metalanguage, and the workings of the wider "repressive and ideological state apparatus". Meer claims that the trial omitted an understanding of the context which prompted Zondo's act. As she proclaims:

The court took an ahistorical view of behaviour, emptying it of its experiential and interactional content. It treated each piece of behaviour as an independent, unconnected entity. It separated Andrew Zondo on the 23rd December, from Andrew Zondo at all other times in his history. It did not want to enter into psychological or sociological dialectics which deflected from the bombing. (65)

Meer's book could be read as a response to the rhetorical discourse of legal procedure, and to its reductionism in establishing the "truth". It is against this backdrop and interpretation that The Trial of Andrew Zondo is set. Meer's intention appears to have been to establish a different truth, one that is situated firmly in a historical context and determined by the essential human right to justice and redress.

The book is divided into four parts. Part One, entitled "The Arrest of Andrew Zondo", opens with a brief reflection on the bomb blast $(3-4)$ followed by Andrew Zondo's appearance in court. As he is brought to trial, we hear his voice for the first time: 
It was a great relief to be out of my cell. For two months I only saw the police. Only once, when I knocked on my cell wall, had I an answer. I found a senior comrade detained in the next cell. In the night when the guards left and we were alone, we talked. He asked me how I was. I told him "okay". Then I told him "I know you can't like me. I have done wrong. People died." He consoled me and said "it was an accident." I said, "They will hang me." $\mathrm{He}$ said I must not talk like that. The next night there was no one in that cell.

Zondo's first words in the book are important in setting the tone and demarcating the space within which his fate would be decided. This was alien territory, marked by a sense of insecurity and solitude. It was a world away from the comforts of home, away from the familiar, away from the support of comrades - and of his accomplice.

In these opening chapters, Meer and Zondo project a deep suspicion of the judicial courts which are represented here as extensions of the enemy's domain. In so doing, they stress the commonality of this perception among many black South Africans: she by evoking the testimony presented by Nelson Mandela at his trial three decades earlier (8); he through his suspicion of pro deo council (7). Particularly through the voice of Andrew Zondo, and by invoking the framework of the struggle, Meer brings into question the legitimacy and authority of the Apartheid State and its legal system.

But she also utilises the opportunity to introduce two points upon which she constructs her own narrative: the first is the relationship between Zondo, a militant political activist, and his deeply religious parents; the second is the contrast between his intense opposition to the state and his respect and care for his family. Ultimately, she questions the validity of the judgement on Andrew Zondo and the truth claims of the South African judicial system.

The use of the metaphor of a journey in biography emphasises continuity and inevitability. In Part Two of her book, Fatima Meer relies on this metaphor to reconstitute Andrew Zondo, the subject of the trial. Here we meet Zondo, born into a religious family, cast into hardship, illness, and relative poverty. Meer describes as littered with contrasts his journey from a small hospital in Port Shepstone, where he was born, to the Scottsburgh Courthouse, where he was tried. As Andrew Zondo recalls:

We lived in a house that belonged to the church on church property. My father was the minister there. But the White ministers who came there were always the most important people. They had cars, and they came to fetch us and take us to their homes.... I did not understand why we had to go to their house. I was always very uncomfortable there.... It made me conscious of myself as an African. (23) 
In highlighting similar contrasts, Meer represents Andrew Zondo's experiences as the general experience of black South Africans. For Zondo this experience ultimately led to his decision to join the ANC and to plant the bomb. Meer presents Zondo's life history as inevitable, literally consisting of a historicallydriven beginning, middle, and end.

Part Three reproduces selections of the court proceedings, with special emphasis on the testimonies of Andrew Zondo (105-126) and the anonymous accomplice-turned-state-witness (93-126). Meer extracts that part of the record which seeks to establish Zondo's frame of mind, his sanity, or lack thereof, at the time of the bombing. She emphasises the bias of the court in its denial of Andrew Zondo's history of "mental illness" (61-79). The state "rejected the defence inference that psychiatry was not an exact science" (81-90) and made counter claims of Zondo's ability to comprehend and project rationally upon his deeds and predicament.

The court records, reproduced in Part Three, form the basis of continuous commentary by Meer. For Meer two problems surfaced around the trial itself. One was a denial of the larger historical context of Andrew Zondo's life, the other was the falsification that took place through the course of the trial with regard to Zondo's mental state. In relation to the latter, Meer refers to the doctor who was recommended by Captain Botha earlier in 1983, for what Andrew Zondo's father, the Reverend Aiken Zondo, felt was a mental illness. At the hearing $a$ doctor claimed that his partner had examined Zondo for what was diagnosed as "joint pains" (90). According to Meer, Andrew and his father independently denied that they had consulted the doctor for pain in the joints. Andrew is reported to have said later that:

That doctor ... [h] said I had a pain in my legs. I never ever had pain in my legs. My parents are not silly to take me to the doctor for a pain in my legs.... When I got to the surgery, I was confused. I was asleep. I just got up there. He gave me an injection and I slept.... [The police] brought him to give the evidence against me. (90-91)

And Reverend Zondo said that:

they had taken Andrew to the doctor because of his deeply disturbed mental state after his detention [in 1983], that they had discussed his condition with the police who had actually paid for them to take him to the doctor. He said that the doctor was told about the mental state, and asked to treat that mental state. There was no question whatsoever about any sort of physical pain. The doctor had lied. (91)

Meer, however, acknowledges the court's claims to truths. In the readings of both the court and Fatima Meer, the meaning of an event is located firmly in its 
historical context, so that history becomes the arbiter of truth (Himmelfarb 1995:131). But for Meer, the court's vulgar reduction of that historical context is problematic. She argues that legal judgements and truths can only be established through employing an enlarged historical context. In making this argument, she suggests that legal trials are only capable of establishing limited "truths" because of their procedural claims to authority and the constraints of judicial rules.

The court has tremendous authority and its ruling is binding on society. It deliberates in terms of its own procedural rules and looks for consistency within these. But rules are relative. A sociologist or psychiatrist would hardly find the court's approach in this particular context acceptable. To uncover the truth they would attempt to resurrect the whole personality, to attempt to understand its total meaning, by integrating the past with the present, by unravelling and restoring repressed memories to comprehend the rationale for a particular act. From the sociological standpoint, the court was atomising Andrew Zondo and judging, not the whole Andrew Zondo, but a legal abstraction, that Andrew Zondo at 10am on December 23rd who had laid a mine and who since had become a memory in time as the act itself. In a sense the court had created a legal fiction to pursue its work of justice.... What Andrew Zondo would be left in court if he was decimated into one event in his life. (Meer 1987:65)

Reflecting on the approaches of both judicial and sociological notions of truth, Meer sets out to construct a history of the accused within a context of politics and experience so as to achieve a greater truth. She establishes a causal succession by replacing a judicial reading of Andrew Zondo with one in which the rhetoric of historical contextualisation looms large. In her view, the construction of an authentic explanation for Zondo's action is therefore dependent on constructing a life in its entirety.

For Meer the notion of context is a linear construction, one in which a continuity between the past and the present is constituted; in this the present invokes the past, and the past informs the present.

Finally, in Part Four, Andrew Zondo's journey comes to an end when:

[he] made his last trip to the court on the morning of April 2. It was a clear summer day and the Indian Ocean was the bluest of blue. But young Andrew Zondo neither saw the sea, nor was he conscious of it.... (161: our emphasis)

The trial comes to an end with the closing arguments, and the conviction of Andrew Zondo as recounted by Meer. Here Meer's own narrative comes to the fore as she uncovers and presents numerous lacunae in the reasoning in the judgement of Andrew Zondo. She questions the overall reliability of the evidence presented by accomplice-turned-state-witness when she states that: 
The court was aware of the dangers of evidences given by the Accomplice, that he would try and implicate the Accused, minimise his own role in the commissioning of the act, and worsen that of the Accused's, and that his moral position was in question being an Accomplice in a serious crime. (143: our emphasis)

She then highlights, by speaking for Zondo, the discrepancies in the trial that culminated in the judgement. The images of Zondo's solitude presented in the opening chapters are mirrored in these closing chapters but here Meer represents a marked irony:

Two men had set out on the 23rd of December 'carrying death' in their bag.

Together they had planted a mine; together they had left the scene, and thereafter turned their backs on the consequences of their act, The one had claimed that he had attempted to phone in a warning: the other made no such claims. The first man was hanged, the other lives.... (163)

Thereafter, Meer invokes her own historical contextualisation of the planting of the bomb, and of the 'struggle' as a whole, tracing a circle of retribution and revenge which is projected backwards into the distant past of "the seventeenth century when the Khoi had made their first guerrilla attack on the Dutch who had occupied their Cape coast and proceeded to push them into the interior" (164: our emphasis).

\section{Lephina Zondo's Testimony}

Lephina Zondo appeared before the TRC on 10 May 1996. Her testimony, presented in Zulu, was translated for the media and the commissioners into English. Her testimony is a transcript of the SABC's recording of the Durban TRC hearing of 10 May 1996 . We reproduce the translated testimony of Lephina Zondo here.

Alex Boraine (TRC Commissioner): ... a first word to you is a word of warm welcome. We thank you very much for coming to the commission and we look forward to hearing your story which is about the execution of your son Andrew but also some attacks on your house which happened to you.

Before we hear the story though, a story of great pain, I want you to please stand to take the oath.... Thank you very much. Mrs Zondo, we always ask some one to help the witness in telling their own story and today I'm that person for you so I'm going to ask you to tell something about your life.

You live in KwaMashu, is that right?

LZ: I live with my family. It's my husband and four children. It's Irene, she's now working, Sandile, he is studying, and Lincoln and the other one are at the primary school.

AB: But another son whose name was Andrew and he was doing matric. Tell me about that. Tell us about that. 
LZ: Andrew left home when he was sixteen and we searched all over for him but we couldn't find him. After his disappearance we stayed home, we were not free, we did not know whether he was alive or not. One day the police arrived and they told us that they got him, they found him. The police told us that it's better to go and see him where he had been arrested. When we went to see him, he was at Westville Prison. We've been visiting him many times and there was a court case and we went to Scottsville (sic) where the case was listened to for the last time. Andrew asked us not to come - me and his father - he said he doesn't want us to be there. $\mathrm{He}$ said he didn't want to be sentenced while we are in the same room.

There was a lawyer, Bheka, [who] represented him. He came back [and] told us that [Andrew had] been sentenced to death five times because of what he did at Amanzimtoti. They took him to Pretoria, they transferred him to Pretoria. We visited him quite often [there], he didn't spend quite a long time at that prison. The police arrived at home to tell us that the day has arrived for him to be hanged, and they said we should go and see him. We left as a family ... We stayed there for the weekend.

They said we can stay in Pretoria but we'll never see his body. We said: "Yes, that is better. Can you make it possible so that we can see his body?"

They said: "No. You will not see his body. You won't be allowed to see his body. You can go and attend the church service but you will never see the body."

We felt that if we go and don't see the body because it's our tradition, before a person can be buried we have got to look at him and be sure that it is the right person. And thereafter we came back and they buried him.

They said they would bury him at Mamelodi and they said they would give us a death certificate after that, but we never received any death certificate.

There was this heavy burden in our hearts. Why didn't they give us the body because they already hanged him. They said no, it's the law, they had to bury him. They said even if we can go we will not see him.

After that there was a memorial service at our house ... [in] KwaMashu. Young and old people attended the service, especially the ones who were UDF during that time. There were others who didn't belong to any organization but most members of the UDF were there. A week had gone by before he could be buried. I don't know whether had he been buried or not, but even after the burial they would come to our house.

One day when they were leaving my house two children were shot dead. These are the children who attended the memorial service and one day, when the memorial service was continuing, the police arrived. On their arrival, they surrounded the house and that time we were singing nkosi sikelel' iAfrika. We were just about to finish the service and the police came in large numbers... They beat up the youth. They didn't touch me. They assaulted the children, the youth, that were in the house.

Duduza, ... my son, was also there. He was heavily assaulted. During the time he had epilepsy. Since ... that incident, he gets these attacks and he passed away. 
Every time since that day he would go to bed and he would cry and say: "Mom, here are the police, they are attacking me", and every time, when he cried, I would go to his room to make sure he was alright. He was attacked by epilepsy 'till he died. I was now left with the remaining ones. They are still alive.

But I must say, during the service the police assaulted the youth terribly. The blood was full in the church and me and my husband were supposed to clean that blood. Dishes were broken...

AB: Don't ... don't rush. When you are ready then you can continue.... Is that your full story?

LZ: Yebo [yes].

AB: Thank you. I won't keep you long because you have carried a very heavy load and you have been very brave. Just one or two short questions.

How old was Andrew when he died?

LZ: He was about to finish his twenty years.

AB: Mrs Zondo, do you remember ever having a meeting with a Mr Smit whose child had died in the bomb attack at Amanzimtoti. Do you remember meeting him?

LZ: Yes, I remember.

AB: Was that a good and helpful meeting for you?

LZ: Yes, that helped me a lot.

AB: Mr Smit came before the commission in Gauteng and he told us about what had happened to his child and he said that he had forgiven Andrew and that he had been very pleased to meet with you so I thought I'd just ask how you felt about that.

I want to ask you just one or two questions about the police attacking your home, the memorial service.

Where did the police come from?

LZ: They came from KwaMashu.

AB: Thank you. Do you remember any of them, did you know them or can you tell us who they were?

LZ: I don't know who they were.

AB: Mrs Zondo, the commission is here to share in your pain and your distress. Is there anything that you would like the commission to do if the commission had the power to do that? Is there anything more you want to say?

LZ: I would request the commission to replace the furniture that belonged to the church and we do not have a death certificate and we cannot go to the place where my son is buried.

AB: Mrs Zondo, we will certainly consider your request and we will very definitely be able to get hold of the death certificate so that you can have it. We will also make enquiries, I'm really not sure what the law is, but we will make enquiries about you son's body and we will come back to you and tell you what we have found out. I hand you now over to the chairperson.

LZ: Thank you very much. 


\section{The Historian, the Commission and the Context}

A workshop of historians and social scientists held in Cape Town on 11 March 1995, noted that a considerable input to the structure, establishment, and the modus operandi of the TRC had been made by religious leaders and social welfare and mental health professionals. The report expressed regret that "the perspectives of historians and social scientists had been largely absent [from the process] so far", warning that, "if not corrected, [this] might lead to important distortions and gaps in the work of the TRC" (Historians, Social Scientists, and the TRC Workshop, 1995). For the historians and social scientists gathered at the workshop, the TRC was constrained by its legalistic approach to questions of evidence, and to questions of truth and reconciliation. What was absent from this approach was the historical and social dimensions, which, it was assumed, could best be rectified via the employment of the historians' and social scientists' skills.

In locating academic discourses within the ongoing deliberations of the TRC, the workshop emphasised a perspective that Andre Odendaal, of the Mayibuye Centre at the University of the Western Cape, had made earlier in arguing for historians to associate themselves more closely with the TRC:

The task of historians is to recover historical evidence, reconstruct past processes and events and help to create an understanding within society and where it is going. In South Africa this is a doubly difficult and doubly important task. We are faced firstly with the problem that the majority of people in the country have been deliberately written out of history. In the memorable words of one of our foremost historians, Colin Bundy, the official South African history has been "to education what the black hole is to matter: a kind of anti-knowledge". (Odendaal 1994:5)

For Odendaal, the TRC had a vital function to perform in restoring silenced voices, and in presenting through an epistemology of evidence, a basis for reconciliation. Almost a year later, those gathered at the workshop argued, in a similar vein, that:

A legal or lawyerly approach to the TRC inevitably tends to focus on questions of individual culpability (of perpetrators) and individual rights to reparation (of victims). This is appropriate, especially as far as the investigation of individual cases by [the] Amnesty Committee and the Committee on Reparation of the TRC are concerned, but it would be a serious mistake to conceive of the overall task and the basic methodology of the TRC in terms of an investigation of individual cases only. If the final report of the TRC would mainly consist of a listing of individual cases, then this will not necessarily contribute to the furthering of national reconciliation. (TRC Workshop 1995) 
As an alternative, it was agreed that a great deal depended on the context and framing of individual cases, during the investigations of the TRC, and in its final report. This, it was believed, could only be attained if "from a historical and social studies perspective ... the investigations of the TRC be grounded in a contextual understanding of the particular historical processes, patterns of social relationships and institutional dynamics relevant to the perpetration of gross human rights violations during this period" and that "this require[s] access to appropriate professional methodologies and expertise" (TRC Workshop 1995).

From the first round of public hearings of the TRC, it has become evident that the testimonies it receives are construed as 'real' stories. But once heard, these testimonies are open to various processes of validation by researchers and investigators. Initially, the TRC "really only want[s] some kind of collaborative evidence - [a certain] level of probability" (Orr et al 1996). Its researchers are not expected to declare a judgment about the 'validity', beyond any reasonable doubt, of the evidence presented to them by victims, bystanders, survivors, or perpetrators, but merely to establish the plausibility of their statements and testimonies.

For members of the research unit, however, it is imperative that, in the attempt to present a complete picture "in words", a balance between the testimonies and a sense of the overall political context within which human rights violations occurred be established.' Here, as in Meer's book, it is proposed that by encapsulating these stories within a 'political' context, we would be able to "see the picture of the nature of the violations".

For the commission, but more specifically, for historians, stories received are real only at the level of evidence, of filling a gap within a totality of what has commonly been referred to as THE South African past. The stories are subsumed into a predetermined or over-determined context, suggesting, we would argue, that subaltern narratives are only realisable once filtered by disciplinary procedures and set against a scientifically established context. Lephina Zondo's voice is subject to the rules which govern the receipt of a testimony in much the same way as a document is mined by an historian for evidence. Her testimony in this instance is read without consideration for silences and outside of multiple domains of power or its relation to how her narrative permeates historical constructions. She instead is read as being without History. She is reduced to a site and an oral source waiting to be processed by a literate elite and inserted into a 'shared national memory'. She occupies the realm of the empirical as she becomes a window to our brutal 'reality'. 
Lephina Zondo is produced in the same way that Andrew Zondo is in the sociological intervention offered by Fatima Meer. This production arises out of the tension between the judge and the historian and is incorporated into particular discursive fields. Lephina Zondo's own horizons will be read as those of the social scientists, historians, and the commissioners for whom she is subject, survivor, witness, and archive. This is apparent in the summary of the hearing produced by the research unit of the TRC which highlighted the following aspects of Lephina Zondo's testimony:

When Andrew Zondo was in matric he told his parents he would leave the country when [he] finished [sic] as he was fed up with the system. His parents never saw him again although once in 1986 he asked them to meet him in Umkomaas, but he had left by the time they arrived there. A week later Andrew was arrested for a bomb blast in an Amazimtoti shopping centre (in which 5 people were killed). His parents attended his trial in [Pietermaritzburg] except for the day of the sentencing as he asked them to stay away. They also visited him on death row in Pretoria where he was executed on the 8th of September 1987. People were attacked leaving the KwaMashu memorial service for Andrew, and two of Majali's grandchildren werekilled. Police assaulted people and destroyed items in the house during the memorial service, Andrew's brother was seriously assaulted and subsequently suffered from epileptic [sic] which finally led to his death. Andrew's mother Lephina has not seen his grave in Mamelodi and was not allowed to see his body after he was executed. ${ }^{2}$

This summary indicates the manner in which Lephina Zondo's testimony is mined for facts. She is rendered voiceless (literally inaudible by the process of translation) and is simultaneously produced as the voice of Andrew Zondo or, at best, of his 'parents'. We learn very little of her pain and personal trauma, of her concerns with tradition, of her belief systems or of her attitudes towards the power of dominant groups and her possible solidarity with the dominated.

\section{Reading Lephina Zondo}

In presenting Lephina Zondo's testimony we have attempted to uncover the strategies through which she permeates the worlds of professional historians and the TRC. We have argued that she is written into history as evidence. In making this point we are not suggesting that she occupies a different space of authenticity or agency. On the contrary, we wish to suggest a possible reading of Lephina Zondo's testimony outside of the authentic/official dialectic, which by extension proclaims a programmatic agenda for historical scholarship.

An interpretation of Lephina Zondo's testimony which might encourage us to imagine the world as radically heterogenous is a reading of the silences in her 
testimony. This approach requires us to read her testimony as a complex historical narrative, informed by a multiplicity of contexts, and to problematise the confined political narrative of resistance that invariably reduces 'stories' to evidence. One possible direction would be to follow Chakrabarty's call for a history that problematises the modern and "writes over the given and privileged narratives of citizenship other narratives of human connections that draw sustenance from dreamed-up pasts and futures" (Chakrabarty 1989:365).

I ask for a history that deliberately makes visible, within the very structure of its narrative forms, its own repressive strategies and practices, the part it plays in collusion with narratives of citizenship in assimilating to the projects of the modern state all other possibilities of human solidarity. (365)

A reading of the testimonies heard by the TRC, along these lines, compels us to read for the silences produced in the testimonies and in the numerous reconstructions of the testimonies. These silences are perpetuated by the disciplinary distinctions between literacy and orality, self and community, official and public. In the example of Lephina Zondo we may allude to one moment in this process of silencing. In her testimony to the TRC, Lephina Zondo alludes to the transgression of "our tradition" where the body has to be seen before it is laid to rest "to be sure that it is the right person". Yet in the TRC's summary of the testimony, cited earlier, there is no mention of her reference to "tradition" nor consideration of what is implied. Perhaps this is one instance, among many, where the testimony of subalterns seems incompatible with a process that is deeply rooted in modernity.

In proposing a shift in the reading of the testimonies presented to TRC we argue that the horizons of Lephina Zondo should be foregrounded. An emphasis on subalternity allows us to read these testimonies beyond new hegemonic projects, systems of legitimation, dominant political discourses and the overarching context provided by historians, social scientists, and the truth commission.

\section{Conclusion}

Meer's book on the trial of Andrew Zondo highlights the tension between academic and judicial approaches to evidence. By reflecting on the outcome of the trial of Andrew Zondo, Meer shows that legal truths are constrained by narrow readings that neglect larger historical contexts. She argues for a reading that contextualises and situates Andrew Zondo as a "historical and social constituent". But in constructing a broader historical context, Meer enlists a linear narrative that implies an even greater claim to truth than that produced through the court hearings. 
With regard to our discussion of Meer's argument, we have shown that a "complete picture of gross human rights violations" is dependent on the synthesis provided by professional scholars and through a construction of a context relevant to understanding what appear to be disparate narratives of trauma and pain. While we are not arguing against this project of contextualisation as it is present in a range of academic, political, and legal discourses that intersect with the work of the TRC, we suggest opening up a transitionary moment to a reading of the ways in which professional historians are implicated in the stories which we tell, the silences we force, and the constraints we encounter and engender.

In this sense we try to show that the rhetoric of contextualisation constrains the subaltern, and possibly renders her unspeakable (yet again), in a project that generally attributes its very legitimacy to those subaltern capacities. To alter the famous dictum of Karl Marx, "men (and women) make history only to be written out of history by Historians".

In the end, as in the beginning, the Truth and Reconciliation Commission will be but a journey from the horizons of the experiences of 'our subjects' to the limits of our understanding, our discourses and our interests.

\section{Acknowledgement}

We would like to thank Gary Minkley, Ciraj Rassool, Leslie Witz, Carohn Cornell and Gitanjali Maharaj for initial comments and Andre Odendaal for access to his collection of truth commission papers.

\section{Note}

1. As laid out in the Promotion of Nation Unity and Reconciliation Act of 1995.

2. We wish to thank the TRC's Research Unit for making this document available to us.

\section{References}

Beresford, David. 1996. Mail and Guardian, April 19-25.

Chakrabarty, Dipesh. 1989. "Postcolonialality and the Artifice of History". In: Veeser, H A (ed). The New Historicism. New York and London: Routledge.

Concise Oxford Dictionary. 1990. 8th edition. Oxford: Clarendon Press.

Davidson, Arnold I. 1994. "Carlo Ginzburg and the Renewal of Historiography". In: Chandler, James, Arnold I Davidson and Harry Harootunian (eds). Questions of Evidence: Proof Practice and Persuasion Across the Disciplines. Chicago and London: University of Chicago Press. 
Premesh Lalu and Brent Harris

Foucault, Michel. 1980. Quoted in Gordon, Colin (ed). Michel Foucault: Power/ Knowledge - Selected Interviews and Other Writings, 19721977. New York: Pantheon.

Ginzburg, Carlo. 1994 "Checking the Evidence: The Judge and the Historian". In: Chandler, James, Arnold I Davidson and Harry Harootunian (eds). Questions of Evidence: Proof Practice and Persuasion Across the Disciplines. Chicago and London: University of Chicago Press.

Himmelfarb, Gertrude. 1995. OnLooking into the Abyss: Untimely Thoughts on Culture and Society. New York: Vintage Books.

Historians, Social Scientists, and the Truth and Reconciliation Commission Workshop, Cape Town, 11 March 1995.

Jauss, Hans Robert. $\quad$ 1982. Question and Answer: Forms of Dialogic Understanding. Minneapolis: University of Minnesota Press.

Krog, Antjie. 1995. "The South African Road". In: Boraine, Alex and Janet Levy (eds). Healing the Nation? Cape Town: Justice in Transition.

Meer, Fatima. 1987. The Trial of Andrew Zondo: A Sociological Insight. Johannesburg: Skotaville Publishers.

Odendaal, Andre. 1994. "The weight of History: Dealing with the Past in South Africa". Paper for the Justice in Transition Conference on Truth and Reconciliation in South Africa, Cape Town, 29-30 July.

Orr, Wendy, Mahlubi Mabizela, and Louis du Plooy. 1996. "Reporting the Past: The Challenge facing the Truth and Reconciliation Commission". Paper delivered at Languages of the Past - How to Remember Things with Words: A Colloquium on Language, Truth and the Past, Cape Town, 7 June.

Spivak, Gayatri Chakravorty. 1989. "The New Historicism: Political Commitment and the Postmodern Critic". In: Veeser, H A (ed). The New Historicism. New York and London: Routledge. 